\title{
Evaluation of Water Resources Demand and Supply for the Districts of Central Narmada Valley Zone
}

\author{
Vinay Kumar Gautam ${ }^{1 *}$ and M.K. Awasthi ${ }^{2}$
}

Department of Soil \& Water Engineering, College of Agricultural Engineering, JNKVV, Jabalpur-482004 (M.P.), India

*Corresponding author

\section{A B S T R A C T}

\section{Keywords}

Water resource, Demand, Supply, Rainfall, Water balance, $C N V$

\section{Article Info}

Accepted:

20 January 2020

Available Online:

10 February 2020
The theme of this paper focused on the water resource availability and demand coupled with projection for future in various sector economy of Central Narmada Valley (CNV) in Madhya Pradesh. The study provides the information about water balance. National Commission on Agriculture (NCA) has given a procedure to compute water budget of a state based on rainfall and water demand by various sectors like crop water management, domestic livestock demand and water demand towards industries. As per NCA guidelines the major input for the water balance of an area is its normal rainfall and when it multiplied by the geographical area it gives quantum of water generated. The annual normal rainfall is 1200 to $1600 \mathrm{~mm}$. The Water available for utilization and demand at zonal level is 728644 ha $\mathrm{m}$ and 565313 ha $\mathrm{m}$ respectively. As for as the excess water concerns the zone has 163331 ha m of surplus water and this is $29 \%$ of total utilization At block level the per unit hectare water availability in Hoshangabad district is $32 \mathrm{~cm}$ while it is $27.5 \mathrm{~cm}$ in Narsingpur district. About $40 \%$ and $60 \%$ Utilizable water resources availability in Narsinghpur and Hoshangabad District respectively. Seoni malwa block of Hoshangabad district in zone level has maximum demand of water has a value 86979.74 ha $\mathrm{m}$. The industrial demand is computed as $6 \%$ of available water thus total zonal demand comes out as 565313 ha $\mathrm{m}$. The relationship between water resource demand and supply is discussed and water balance in the various provinces determined.

\section{Introduction}

Water budget is a demand and supply analysis of water resources. The major input for the water balance of an area is its normal rainfall and when it multiplied by the geographical area it gives quantum of water (Surface and Ground water) generated. Water demand of a single district is computed by adding water consumed by different sectors viz. agriculture, domestic, livestock and industrial. A study shows that the water demand towards domestic use and for livestock is much less than the water required towards crops. About $80 \%$ of utilizable water is consumed by the agriculture sectors. Water adequacy aims towards optimum use of water to get maximum production and maximum net 
return with available land resources. The Agro climatic zone IV - Central Narmada Valley has two districts namely Hoshangabad and Narsingpur and comes under Wheat zone having black soils. Annual normal rainfall of zone varies from 1200 to $1600 \mathrm{~mm}$. The annual rainfall exceeded $14.6 \%$ and $32.3 \%$ times than the normal annual rainfall in Hoshangabad and Narsingpur districts respectively.

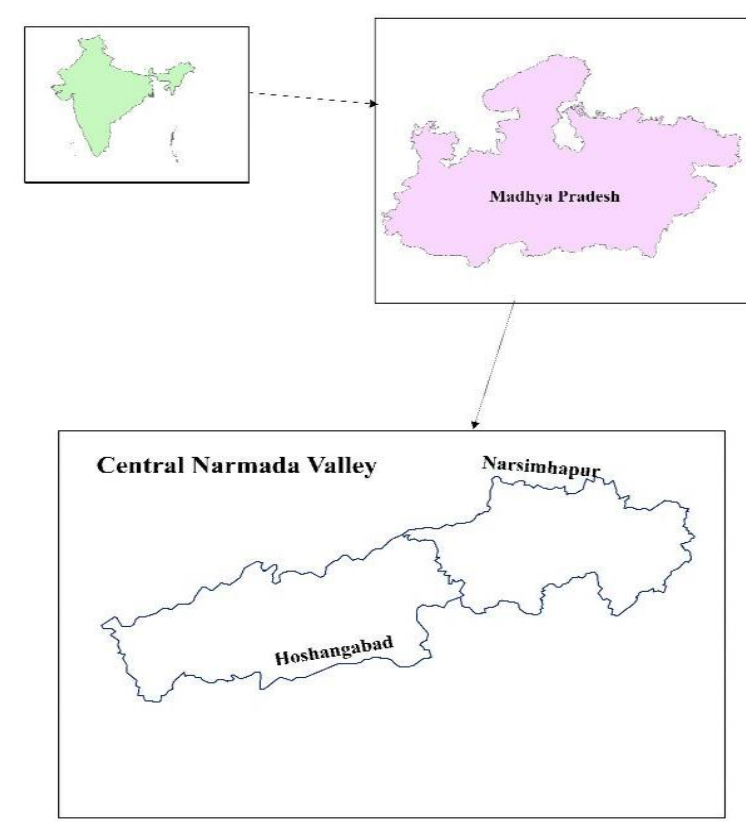

Fig.1 Location of Study area

Rainfall is the prime and sole input of water to any area. Central Narmada Valley receives total quantum of water towards rainfall as 1599893 ha m. Singh et. al. (1999) presented a water resource assessment approach based on water balance analysis of huruluwewa watershed Silence. Watershed based water management approach was found to be feasible option to alleviate the problem of water scarcity.

They concluded that water resource planning is strongly linked to land use planning. The Analysis of monsoon rainfall variability over Narmada basin in central India suggested that appropriate measures may be proposed for better management of the water resources in the basin (Thomas et. al., 2015). The main objective of this study is to assert the best estimates for water demand and supply in the Central Narmada Basin for various purposes at present as well as the future. We argue here that the current supply and demand can be partially balanced in that region by available strategic water resources that are not yet utilized and through rational use of water from recycling/treatment of these unexploited water resources. We justify this by showing that the region has a large footprint from the demand side, with so far only a single source from the supply side, and that supplying sufficient quantity and quality of $\mathrm{PW}$ is a good and a manageable option.

This is shown by calculating demand and supply for irrigation, industry, domestic and livestock purposes to determine the water balance and water shortages, based on Information from the authentic data from international and national institutes and sometimes locally available information sources. This is study will help to quantifies the water resources demand and supply for the Central Narmada Basin and proposes better implementation of solutions to the water scarcity in the region.

\section{Materials and Methods}

This study has three components: 1 . Assessment of water resources, 2. Estimation of water demand and 3. Evaluation of current water demand-supply status. Data used in the assessment include climate data (rainfall, temperature), census (demography, livestock), water demand of different sectors and agricultural production and industry. Water resources assessment for the districts was done from 1970 to 2015 using observed rainfall inputs. 
Assessment of utilizable water resources in cnv

\section{Total water resources}

The total amount of local water resources here includes both surface water (natural runoff) and ground water. So, the total water resource available for utilization at zonal level is 728644 ha $\mathrm{m}$ in 2015 (of which the utilizable surface water was 351718 ha $\mathrm{m}$ ). This is $12.5 \%$ more than the year before, $1.5 \%$ more than the annual average amount between 1970 and 2015, Ground water also adds to the surface flow and it is taken as $23.739 \%$ of surface flow. According to NCA guideline, Water available for ground water storage is $12.5 \%$ of precipitation. The total ground water available is $21.492 \%$ of total precipitation. $31.625 \%$ of total ground water is available for ground water utilization.

\section{Water demand}

From the population Figures of 2011 census, the present population and projected population for 2020 was estimated considering the prevailing growth rate of $12.5 \%$. Following data was used, to characterize urban, agricultural and industrial water demand.

1. Human population 2. Animal population 3 . Crop irrigation

\section{Water requirement of crops and Irrigation}

Water needs for growing crops depend mainly on crop type and climate conditions. Such water can be supplied to the crops by rainfall, irrigation, or a combination of the two. Detailed water demands for irrigation was estimated of various crops that are grown in the four provinces in the valley. The zone is a Wheat zone has 353429 ha under wheat in which Hoshangabad has contribution of 73.6\%. Rice grown in 59303 ha. Other major crops are gram (134819 ha), Pigeon pea (33872 ha). Narsingpur is dominated in pigeon pea $(99.1 \%)$ and pulse cultivation (94.3\%). Sugarcane is also coming up in steady way as now it is grown in 40960 ha area of Narsingpur.

\section{Domestic Water Demand}

Domestic water demand includes use for drinking, preparing food, bathing, washing clothes and dishes, air conditioning, gardening and other household purposes. Total population of the zone is 2333116 as per Census 2011. For domestic purpose per capita water requirement is 135 liter/day as per the WHO recommendations. According to this the total domestic water requirement is calculated. Although the water requirement for urban and rural areas varies a lot, this figure is adopted for understanding of the gravity of the situation accordingly.

\section{Livestock Water Demand}

To assess the demand quantitatively, we estimated the water required for livestock farming and breeding according to norms given by WHO in daily basis. Narsingpur has more cross breed cattles as against Hoshangabad as its percentage is $13.5 \%$ in comparison to Hoshangabad percentage of $6.1 \%$ of total available cattles of these districts. Both districts have scope of breeding improvement programmes.

\section{Industrial Water Requirement}

The river banks of the both districts are surrounded by small industries like marvel, sugar, lather and gelatin industries and the main sources of water for the industrial sector are fresh groundwater and surface water. The positive side of this trend is that water used in industrial processes can be recycled, unlike in agriculture where very little of it is actually 
consumed. In India, the water demand for the industrial sector is on a rise and will account for 8.5 per cent of the total freshwater abstraction in 2025, the current level of 6 per cent of the total freshwater abstraction by the industries in 2010. (FICCI Water Mission, New Delhi, 2011).

\section{Water budget}

Water budget is a necessary tool to estimate the gap between demand and availability of water resources from different sources. National Commission on Agriculture has laid down norms for water budgeting of an area and as per its estimate the losses of water as evaporation, surface water flow and ground water flow out of the area is calculated in present estimation.

Similarly, addition of water into the area as runoff generated from the zone, addition of soil moisture and to the ground water is also computed. The available water within zone is the sum of the district contribution. The relationship between water availability was addressed by water balance accounting and order of priority. The basic demand (Domestic and agriculture) has the highest priority followed by the normal (Livestock and Industry) demand.

\section{Results and Discussion}

Efficient water distribution strives to use robust techniques to estimate the water availability and demand, setup evaluation tools. In addition to quantify the available water resources and assessment procedures need to address the relationship between available water and biological indicators of an adequate environmental flow (Jain, 2012; Richter et al., 2003). A NCA norms were used to assess water resource availability and demand in data limited valley. Input data requirement and data processing and strategies were discussed. This study exploited the rank of relationship between availability and demand to assess water resource status in the $\mathrm{CNV}$.

\section{Utilizable water resources}

The Central Narmada Valley (CNV) has two district based on factors that influence water resources availability and use. Annual normal rainfall is 1200 to $1600 \mathrm{~mm}$. The annual rainfall exceeded $14.6 \%$ and $32.3 \%$ times than the normal annual rainfall in Hoshangabad and Narsingpur districts respectively. The distribution of rainfall in the zone is shown in fig. 1. The amount and onset of rainfall in the zone vary with location. Central Narmada Valley receives total quantum of water towards rainfall as 1599893 ha $\mathrm{m}$. the total water resource available for utilization at zonal level is 728644 ha $\mathrm{m}$ in 2015.

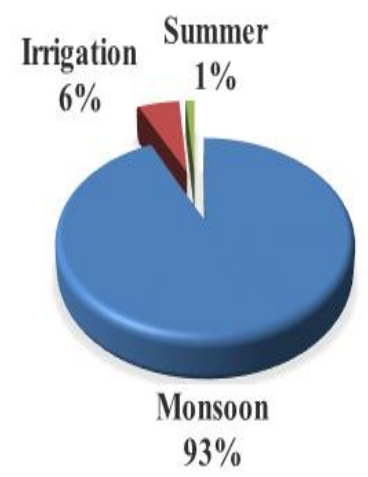

Fig. 1.1 Distribution of rainfall in CNV zone

\section{Water demand}

\section{Domestic and Livestock water demand}

Total population of the zone is 2333116 as per Census 2011. Total human water needs of the zone is 11496 ha m. Livestock population comprises of cattle both cross breed and indigenous, buffalo, bovine, sheep, goat, 
horses and ponies, mules, donkey, pigs, dogs, rabbits, fowls, ducks, turkey and other poultry. Narsingpur has more cross breed cattles as against Hoshangabad as its percentage is $13.5 \%$ in comparison to Hoshangabad percentage of $6.1 \%$ of total available cattles of these districts. Both districts have scope of breeding improvement programmes. Bovine is the main cattle class (900871) followed by population of buffaloes (239756). Except fowls in the Hoshangabad (154219) which is three times more than the Narsingpur all other animals are found in these two districts are more or less of the same quantity.

\section{Water requirement of crops}

The zone is a Wheat zone has 353429 ha under wheat in which Hoshangabad has contribution of $73.6 \%$. Rice grown in 59303 ha. Other major crops are gram (134819 ha), Pigeon pea (33872 ha). Apart from this other pulses (Rabi) are also taken in 56669 ha and in Kharif. It occupies 87346 ha. Narsingpur is dominated in pigeon pea $(99.1 \%)$ and pulse cultivation $(94.3 \%)$. Sugarcane is also coming up in steady way as now it is grown in 40960 ha area of Narsingpur. For the zone Wheat is the major Rabi crops and its water requirement is 13640 ha $\mathrm{m}$. Sugarcane is another crop water requirement is 38450 ha m.

\section{Water budget}

The Agro climatic zone- Central Narmada Valley receives total quantum of water from rainfall as 1599893 ha $m$. National Commission on Agriculture has given some guidelines for water budgeting of an area and as per its estimate the losses of water as evaporation, surface water flow and ground water flow out of the area. Ground water also adds to the surface flow and it is taken as $23.739 \%$ of surface flow.
Thus, surface flow arrives to be 723120 ha m which is $45.198 \%$ of total precipitation. The soil moisture increases due to rainfall as well as from irrigation. $41.3 \%$ of rainfall and $7.067 \%$ of total surface flow is considered as soil moisture storage. Total zonal soil moisture storage is 711872 ha $\mathrm{m}$ and out of this 268184 ha $\mathrm{m}$ is available as ET for the crops. Utilization of water takes place in four major categories. These are, domestic and animal water needs, crop water requirement and requirement of water for industrial purposes. A water demand of different sectors in districts of zone is presented in Fig. 2.

Total crop water requirement of the zone is 490886 ha $\mathrm{m}$. In comparison to the crop water demand the water demand towards domestic and animal husbandry is very low as it is respectively 11496 ha $\mathrm{m}$ and 8844 ha $\mathrm{m}$. The industrial demand is computed as $6 \%$ of available water thus total zonal demand comes out as 79129 ha m.Total Water supply and demand of different districts of zone is presented in Fig. 3. The Excess is also shown. The Water available for utilization at zonal level is 728644 ha $\mathrm{m}$. As for as the excess water concerns the zone has 163331 ha $\mathrm{m}$ of surplus water and this is $29 \%$ of total utilization. Considering net sown area as 623303 ha the average depth of excess water available per hectare is $26 \mathrm{~cm}$.

At district level the per unit hectare water availability in Hoshangabad is $34 \mathrm{~cm}$ while it is $18 \mathrm{~cm}$ in Narsingpur district. It means, the future plans to enhance crop production or alternate cropping may be based on this much depth of water. on and industrial growth driven by increased wealth. The water needed for irrigation may also increase due to climate change besides the effect of population growth; however, in the zone, effect of population growth on water demand will be much larger than that of climate change. 


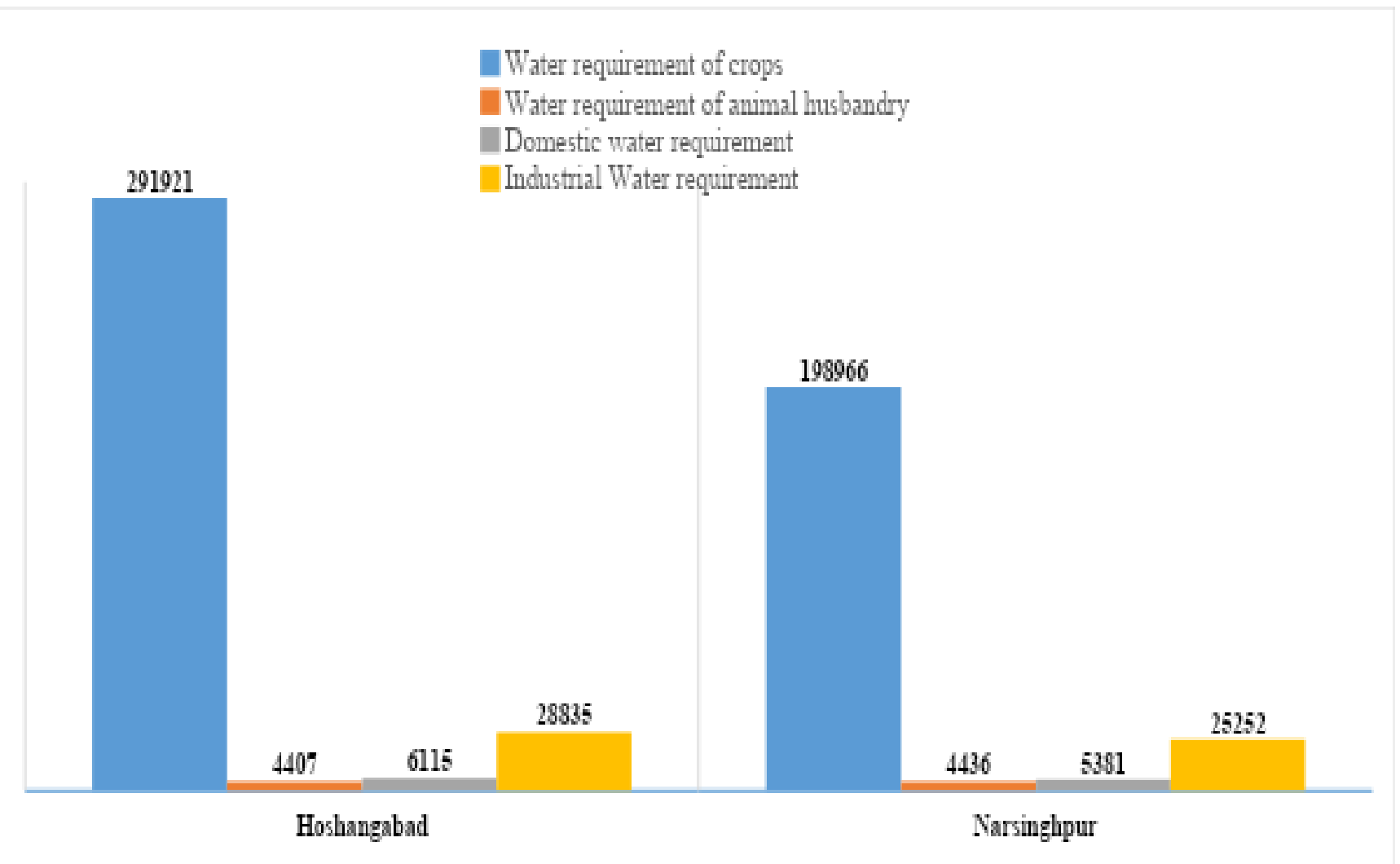

Fig.2 Water demand of different sectors in districts of Central Narmada Valley zone (ha m)

Water available for utilization, ha $\mathrm{m}$

Water required for different sectors, ha m

Surplus or deficit of water in the district, ha $\mathrm{m}$

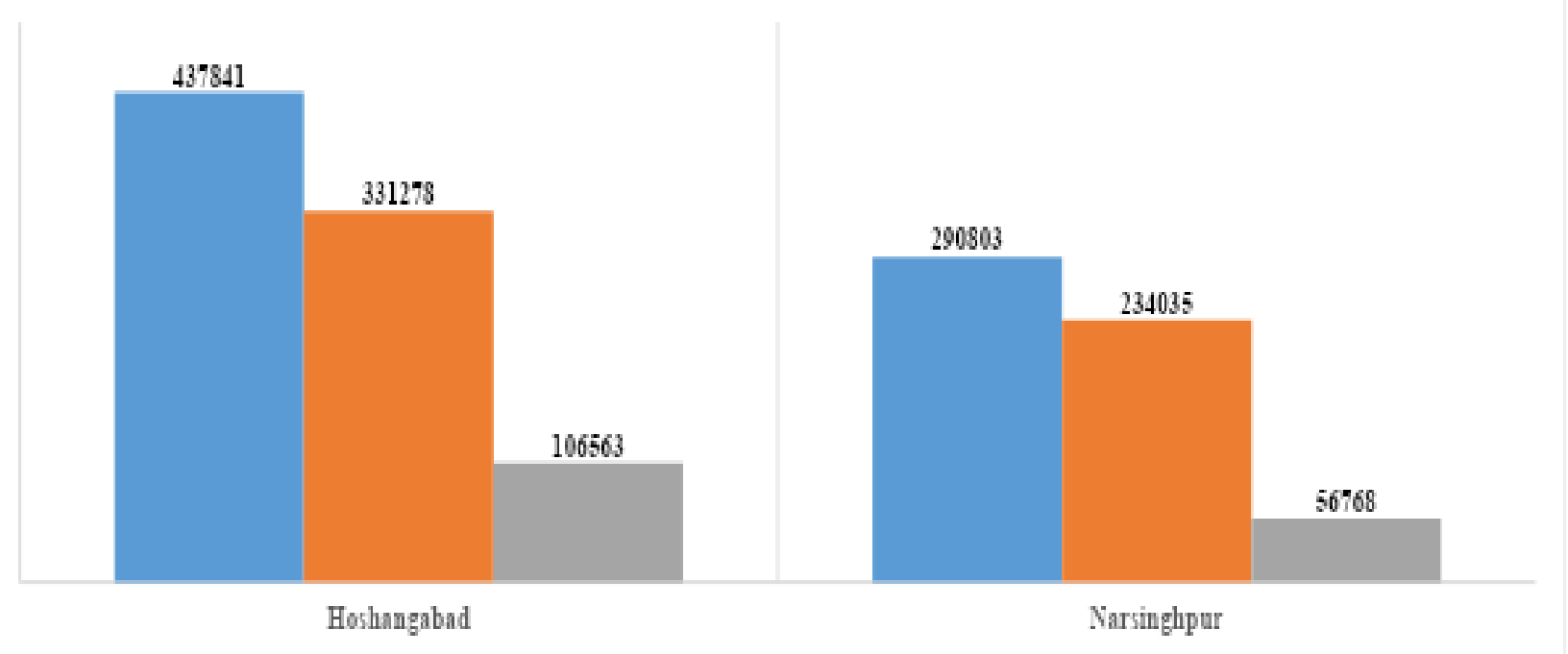

Fig.3 Total utilizable water resources demand and supply of both districts of Central Narmada Valley zone (ha m) 


\section{Conclusions}

As we can see that water shortage in present time in the CNV zone is not a serious issue that will be expected to worsen in the future because of population growth, increased abstractions upstream, poor management of the available water resources and climate change. The Water available for utilization at zonal level is 728644 ha $\mathrm{m}$ as compared to 565313 ha $\mathrm{m}$ for water demand. Analysis shows that the $45 \%$ and $60 \%$ of utilizable water is used as crop irrigation purposes in Narsinghpur and Hoshangabad district of the zone respectively. This study represents the most interesting scenario that water consumption (water demand) can be manage by knowing that crop water requirement is the most water consumer sector in the study area. The study also provides insight to the vulnerability of the water resources in $\mathrm{CNV}$.

\section{References}

Anonymous. 2002a. National Commission on Agriculture, Ministry of Agriculture and Irrigation, Govt. of India, New Delhi.

Anonymous. 2002b. National Water Policy, Ministry of Water Resources, Govt. of India, New Delhi.

Anonymous. 2005. Water Supply \&Water Demand and Agricultural Water Scarcity in China: A Basin Approach. International water management institute.

Anonymous. 2015a. District Statistical Book. District Statistics and Planning Department, Narsinghpur, Govt. of M.P.

Anonymous. 2015b. District Statistical Book. District Statistics and Planning Department, Hoshangabad, Govt. of M.P.

Awasthi MK, Tomar VS, Nema RK, Lodhi AS, Srivastava RN, Sharma SK, Pyasi SK. 2018.A Book on Water Budgeting of Madhya Pradesh, College of Agricultural Engineering JNKVV, Jabalpur, M.P.

Bhat NR, Lekha VS, Suleiman MK, Thomas B, Ali SI, George P and Al-Mulla L.2012 .Estimation of water requirements for young date palms under arid climatic conditions of Kuwait. World Journal of Agricultural Sciences 8 (5), pp 448-452.

Dessu Shimelis Behailu, M. Melesse Assefa, Bhat Mahadev G., McClain Michael E.2014. Assessment of water resources availability and demand in the Mara River Basin. Catena 115 (2014) 104114.

FICCI. 2011. Water Risk in Indian industry survey report, a report published by FICCI, New Delhi.

Jain SK. 2012. Assessment of environmental flow requirements. Hydrol. Process. 26, pp 3472-3476.

K.K Liu, Li CH, Yanga XL, Hua J, Xiaa XH.2009. Water Resources SupplyConsumption (Demand) Balance Analyses in the Yellow River Basin in 2009.2012. The 18th Biennial Conference of the International Society for Ecological Modelling. Procidia Environmental science 13(2012), pp 1956-1965.

Kiniouar Hocine, Hani Azzedine, Kapelan Zoran. 2017. Water Demand Assessment of the Upper Semi-arid Sub-catchment of a Mediterranean Basin. International Conference on Technologies and Materials for Renewable Energy, Environment and Sustainability. Beirut Lebanon. Energy Procedia 119 (2017), pp 870-882.

Mustafa Al-Furaiji, Karim Usama, Hulscher Suzanne, Waisi Basma. 2016. Evaluation of water demand and supply in the south of Iraq. Journal of Water Reuse and Desalination, pp 214-226.

Richter BD. Mathews R, Harrison DL, 
Wigington R. 2003. Ecologically sustainable water management: managing river flows for ecological integrity. Ecol. Appl. 13, 206-224.

Singh AK, Prinz D and Makin IW. 1999. Water resource assessment as a basis for watershed management. A study from Huruluwewa, Srilanka 2nd Inter-
Regional Conference on Environment Water 99.

Thomas T, Gunthe SS, Ghosh NC, Sudheer KP. 2015. Analysis of monsoon rainfall variability over Narmada basin in central India: Implication of climate change. Journal of Water and Climate Change. pp 615-627.

\section{How to cite this article:}

Vinay Kumar Gautam, Awasthi M.K. 2020. Evaluation of Water Resources Demand and Supply for the Districts of Central Narmada Valley Zone. Int.J.Curr.Microbiol.App.Sci. 9(02): 3043-3050. doi: https://doi.org/10.20546/ijcmas.2020.902.350 